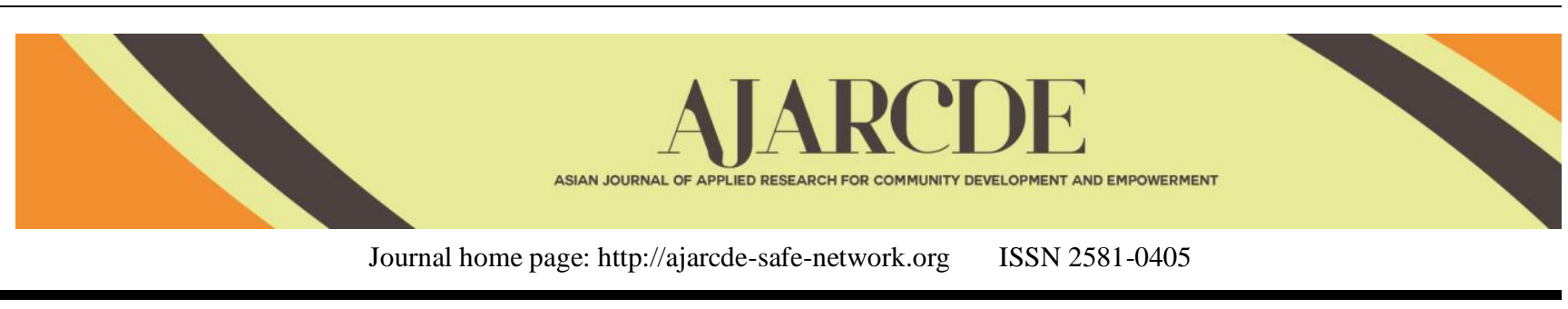

\title{
Utilization of Eco-Enzymes from Fruit Skin Waste as Hand Sanitizer
}

\author{
Rusdianasari $^{1}$, Adi Syakdani ${ }^{1}$, Muhammad Zaman ${ }^{1}$, Febby Fitria Sari ${ }^{1}$, Nabila Putri Nasyta ${ }^{1}$, Rizka \\ Amalia ${ }^{1}$ \\ Department of Chemical Engineering, Politeknik Negeri Sriwijaya, Jalan Srijaya Negara, Palembang, Indonesia
}

\section{ARTICLE INFO}

Article History:

Received: 11 August 2021

Final Revision: 30 September 2021

Accepted: 2 October 2021

Online Publication: 16 October 2021

\section{KEYWORDS}

Eco-enzyme, hand sanitizer, pineapple,

\section{CORRESPONDING AUTHOR}

*E-mail: rusdianasari@polsri.ac.id

\begin{abstract}
A B $\mathbf{S}$ T $\mathbf{R}$ A $\mathbf{C}$ T
Eco-enzyme is a multifunctional liquid produced from the fermentation of waste or organic waste, brown sugar or granulated sugar, and water. Fermentation of eco-enzymes is carried out for \pm 3 months. The length of time fermentation affects color, aroma, and $\mathrm{pH}$. The eco-enzyme liquid is dark brown and has a strong fresh sour aroma. Eco-enzyme liquid has an alcohol content and acetic acid. Alcohol and acetic acid are produced from the bacterial metabolic process that is naturally present in the rest of fruits and vegetables. Variations in the length of fermentation of eco-enzymes used are 2.5 months and 3 months. Analysis conducted on eco-enzymes includes $\mathrm{pH}$ tests and phytochemical screening tests. The $\mathrm{pH}$ value obtained in eco-enzyme with 2.5 months fermentation length is 3 , while the $\mathrm{pH}$ value in eco-enzyme with 3 months fermentation is 1.5 . Ecoenzymes with a fermentation time of 3 months contain alkaloid compounds, flavonoids, saponins, and tannins. In this study, Eco-enzyme was used as a hand sanitizer spray by diluting the eco-enzyme with distilled water. The dilution ratios used vary for each sample: 1:40, 2:40, 3:40, 4:40, 5:40. Analysis conducted on hand sanitizer spray includes $\mathrm{pH}$ test, organoleptic test, and antibacterial activity test. Based on the results of the analysis, not all hand sanitizer samples meet SNI standards, the best samples obtained in hand sanitizer with an eco-enzyme fermentation length of 3 months and a dilution ratio of 5: 40. The results of the analysis showed that the value of $\mathrm{pH} \mathrm{5,} \mathrm{the} \mathrm{level} \mathrm{of} \mathrm{aroma}$ fondness in hand sanitizer of 2.40 , the favorite color level of 2.46
\end{abstract}

\section{INTRODUCTION}

\subsection{Research Background}

Organic waste that can be broken down through biological processes easily rot, such as food waste, vegetables, pieces of wood, dried leaves, and so on. Organic household waste until now is still a problem that has not been resolved properly and correctly. The state of waste that is increasingly becoming abundant and piling up results in pollution to the surrounding environment [1]. Therefore, household organic waste should be reprocessed into versatile products such as eco-enzymes so as not to pollute the environment. One of the household organic waste that can be used as an eco-enzyme is fruit peel, pineapple skin, papaya skin, and vegetable residue mixture.

The eco-enzyme can be used as a hand sanitizer. Hand Sanitizer is an alcohol-based hand sanitizer used to kill microorganisms by using without rinsing with water. Hand sanitizer preparations are hand sanitizers that are practical and easy to carry everywhere and have antiseptic content. In hand sanitizers from eco-enzymes, the addition of alcohol is not needed because in the eco-enzyme there is alcohol content and acetic acid that serves to kill germs. These alcohols and acetic acid are produced from the fermentation process of eco-enzymes, so the hand sanitizer of this eco-enzyme does not irritate the hands [2][3].

\subsection{Literature Review}

Orange peel contains several compounds that can be further utilized, such as the content of essential oils in it. Orange peel contains a variety of substances, the most dominant of which are essential oils and pectin). Sweet orange peel contains essential oils. The content of essential oils in orange peels is $2.49 \%$. Chemically, orange peel contains essentials consisting of components such as terpenes, sesquiterpenes, aldehydes, esters, and sterols [4]. Essential oils have anti-fungal or germ-eradicating properties and are a component needed to inhibit anti-microbial pathogenic bacteria [5]. Benefits of sweet orange peel in addition to being anti-depressants, tonics, strep throat reliever, and cough, are also useful as antiseptics. Orange peels also contain pectin by $15-25 \%$.

Pineapple skin has active substances including anthocyanins, vitamin $\mathrm{C}$, and flavonoids. In addition, there are the enzymes 
bromelain and tannin [6]. Positive pineapple skin contains tannins, saponins, steroids, flavonoids, phenols, and other compounds. It contains a total of $38.95 \mathrm{mg} / 100 \mathrm{gr}$ of antioxidants with bioactive components in the form of vitamin $\mathrm{C}$ of 24.40 $\mathrm{mg} / 100 \mathrm{gr}$, beta carotene by $59.98 \mathrm{ppm}$, flavonoids $3.47 \%$, quercetin $1.48 \%$, phenols $32.69 \mathrm{ppm}$, and saponins $5.29 \%$ [7].

Papaya fruit skin also contains folate, vitamin A, magnesium, copper, pantothenic acid, fiber 3, vitamin B complex, beta carotene, lutein, zeaxanthin, vitamin E, calcium, potassium, vitamin $\mathrm{K}$, lycopene, and the enzyme papain. Papaya fruit peel contains fiber, ash, phenolic compounds, vitamin $\mathrm{C}$, some potassium, sulfur, and copper materials [7]. Analysis of the content of phenolic compounds and vitamin $\mathrm{C}$ papaya skin is higher than the seeds of papaya. The antioxidant content of papaya fruit skin extract is higher than the of papaya fruit seed extract. In addition, papaya fruit skin contains much more papain enzymes, especially in young fruit skins, as well as other secondary metabolite compounds such as alkaloids, flavonoids, saponins, and others.

Palm sugar is one of the processed foods sourced from the treatment of coconut sap derived from bunches of male flowers of the palm tree. The content in palm sugar is quite an important role to help meet the body's needs for certain nutrients [8]. Palm sap processed into palm sugar must meet the $\mathrm{pH}$ requirement of $6-7.5$ and Brix levels above $17 \%$, as well as the quality of palm sugar produced, is good [9]. In palm sugar, there is a large number of antioxidants. The content of these antioxidants can ward off free radicals, so it can protect the body from the threat of dangerous diseases such as skin cancer [10]. In the fermentation process, brown sugar plays an important role in the production of eco-enzymes. This is because sugar (sucrose) has an important role as a source of nutrition for bacterial growth, where the higher the content of sucrose the more volume produced after the fermentation process.

Eco-enzyme was first developed by Dr. Rasukan Poompanvong from Thailand [11]. Eco-enzyme is a multifunctional liquid produced from the fermentation of waste or organic waste, brown sugar or granulated sugar, and water. The manufacture of eco-enzymes has a broad impact on the environment globally and in terms of economics. Judging from its benefits to the environment, during the fermentation process (starting from day one) it will produce and release $\mathrm{O}_{3}$ gas known as ozone. This ozone will work under the stratosphere to reduce greenhouse gases and heavy metals confined in the atmosphere. In addition, $\mathrm{NO}_{3}$ and $\mathrm{CO}_{2}$ gases are also produced that are needed by the soil as nutrients for plants [12].

The fermentation process of the formation of eco-enzymes produces gas. During fermentation, carbohydrates are converted into volatile acids and in addition, the organic acids present in waste materials also dissolve into fermentation solutions because the $\mathrm{pH}$ of waste enzymes is acidic [13]. In the fermentation process, glucose is overhauled to produce pyruvate acid. Pyruvic acid in anaerobic conditions will be decomposed by pyruvate decarboxylase into acetaldehyde, then acetaldehyde is converted by alcohol dehydrogenase into ethanol and carbon dioxide, where Acetobacter bacteria will convert alcohol into acetaldehyde and water, which then acetaldehyde will be converted into acetic acid. After a perfect fermentation process, eco-enzymes (dark brown liquids) are formed. Eco-enzyme liquids can be used as versatile cleaning fluids such as hand sanitizers and disinfectants in addition eco-enzymes can be utilized as insecticides, and dregs from eco-enzymes can be used as organic fertilizers [14][15].

\subsection{Research Objective}

This research aimed to study the effect of eco-enzymes dilution variation and the length of eco-enzymes fermentation on the quality of hand sanitizer according to Indonesian National Standard (SNI).

\section{MATERIALS AND METHODS}

\subsection{Research Treatment}

Raw materials used in the manufacture of eco-enzymes in the form of orange peel, pineapple peel, papaya skin obtained from household waste. In addition, brown sugar is also used as molasses. The analysis conducted in this study was conducted at the Laboratory of Bioprocess Engineering and Basic Analysis of Sriwijaya State Polytechnic, Indonesia.

\subsection{Design Experiment}

This research process consists of 4 main stages, namely the stage of making eco-enzymes, the stage of eco-enzyme analysis, the manufacture of hand sanitizer from eco-enzymes, and the stage of analysis of hand sanitizer. The study was conducted based on the length of fermentation time of eco-enzymes with a variation of 2.5 months and 3 months. In addition, variations of the dilution of eco-enzyme into hand sanitizer include 1:40, 2:40, 3:40, 4:40, and 5:40.

\section{3. $\quad$ Research Procedure}

In the manufacture of eco-enzymes, the main thing to do is to clean the waste of orange peel, pineapple, and papaya using clean water to be free from dirt that comes with the fruit skin. In addition to skin waste, palm brown sugar is also used which is useful as molasses. The peel of the fruit and brown sugar that has been finely cut is mixed into a jar that has contained water and stirred homogeneously. Once all is mixed, the jar is tightly sealed and fermented for \pm 3 months. During fermentation the jar is stored at room temperature, lighting and sterilization of the equipment also determine the finished level of the product. Ecoenzyme products can be harvested after \pm 3 months of fermentation. Harvesting the product is done by filtering the liquid to separate the dregs.

Eco-enzyme products that have been filtered are put into clean bottles that will then be used as hand sanitizers. The utilization of eco-enzyme into hand sanitizer is done by diluting the eco-enzyme using aqua dest with dilution variations of $1: 40$, $2: 40,3: 40,4: 40$, and 5:40. Once diluted, the hand sanitizer is put in a clean bottle.

\subsection{Data Processing and Data Analysis Techniques}

In this research, the data is presented in the form of tables according to the type of variables that describe the results of ecoenzyme analysis and hand sanitizer. The data analysis conducted in this study is a pH analysis conducted by measuring the standard color that occurs in the universal $\mathrm{pH}$ paper dipped in each sample.

Phytochemical tests are performed to detect active compounds based on their group to find out the group of chemical compounds that have the biological activity of a plant. These 
phytochemical tests include alkaloid compounds, flavonoids, saponins, and tannins.

Organoleptic testing is carried out using hedonic methods aimed at making sure hand sanitizer spray products are acceptable to the public. The way to test is done by filling out a questionnaire and comparing the color and aroma of hand sanitizer. Antibacterial activity tests are carried out by making a medium from Nutrient Agar (NA), then implanting the bacteria in the hands directly and incising for 48 hours.

\section{RESULT AND DISCUSSION}

\subsection{Eco-Enzyme Characteristic}

In the manufacture of eco-enzymes anaerobic fermentation (without oxygen) and carried out with a variation of 2.5 months and 3 months. Before fermenting the fruit skin waste is cleaned first to prevent the presence of spoilage bacteria. The results of the analysis on eco-enzymes can be seen in Table 1 .

Table 1. Eco-Enzyme Characteristic

\begin{tabular}{|lll|}
\hline $\begin{array}{l}\text { Fermentation } \\
\text { Time }\end{array}$ & Observation & Test Results \\
\hline 2.5 months & $\begin{array}{l}\text { Observation } \\
\text { Sensory }\end{array}$ & $\begin{array}{l}\text { Liquid, brown color } \\
\text { Fresh lemon aroma }\end{array}$ \\
& $\mathrm{pH}$ & 3 \\
3 months & $\begin{array}{l}\text { Observation } \\
\text { Sensory }\end{array}$ & Liquid, brown color \\
& $\mathrm{pH}$ & 1.5 \\
\hline
\end{tabular}

Eco-enzyme is a multifunctional liquid produced from the fermentation of waste or organic waste, sugar, and water. The manufacture of eco-enzymes is done using an anaerobic fermentation process. Anaerobic fermentation is an attempt by bacteria to obtain energy from carbohydrates in anaerobic conditions (without oxygen) byproducts in the form of alcohol or acetic acid depending on the type of microorganism. Based on Table 1 can be seen in fermentation 2.5 months obtained a $\mathrm{pH}$ value of 3 , while for fermentation 3 months obtained a $\mathrm{pH}$ value of 1.5. This shows that the longer the fermentation time, the lower the $\mathrm{pH}$ produced because the acidity level produced is also higher. Therefore, the $\mathrm{pH}$ indicator in eco-enzyme fermentation with a time of 3 months has a lower $\mathrm{pH}$ value compared to the $\mathrm{pH}$ value with a fermentation time of 2.5 months.

In the phytochemical test, eco-enzymes with a time of 3 months were better than eco-enzyme products with a fermentation time of 2.5 months. This is because the eco-enzyme product test with a fermentation time of 3 months was identified as having alkaloids, flavonoids, saponins, and tannins, while ecoenzyme tests with a fermentation time of 2.5 months identified the absence of alkaloid content in it, but only contained flavonoids, saponins, and tannins. Alkaloids, flavonoids, saponins, and tannins are useful content as antioxidants, antibacterials, and antifungals.

\subsection{Eco-enzyme as hand sanitizer}

Eco-enzyme is used as one of the alternatives in the manufacture of hand sanitizer. Hand sanitizer sprays from ecoenzyme do not require additional alcohol, because in eco-enzyme there is alcohol content and acetic acid which is the result of the fermentation process of bacterial metabolism naturally from the skin of fruits and vegetable waste.

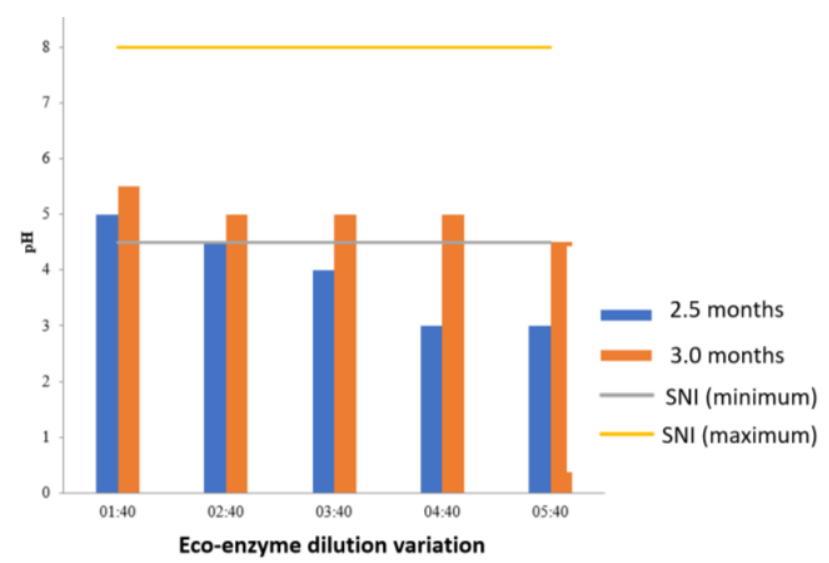

Figure 1. pH of Eco-Enzyme Based Hand Sanitizer

Based on Figure 1 it can be seen that the $\mathrm{pH}$ value obtained in the hand sanitizer varies according to the variables tested. One of them is shown by changes in $\mathrm{pH}$ values influenced by varying variations in eco-enzymes, where the more volume of ecoenzymes used, the $\mathrm{pH}$ value obtained decreases or the more acidic. Figure 1 shows that hand sanitizers with a time variation of 2.5 months have a $\mathrm{pH}$ value ranging from $3-5$, where 3 out of 5 samples tested do not meet the $\mathrm{pH}$ quality standard requirements following SNI 06-2588-1992. The $\mathrm{pH}$ value in hand sanitizer with a variation of eco-enzyme 3 months has a $\mathrm{pH}$ value that ranges from 4.5-5.5, where the $\mathrm{pH}$ value meets the standard quality requirements of the hand sanitizer $\mathrm{pH}$ value following SNI 06-2588-1992. The $\mathrm{pH}$ test is also performed as well as an emulsion stability test, which shows the formulated hand sanitizer is stable and does not form clumps.

Bacterial testing is done by the swab method on the palm or finger of the hand. This antibacterial test used negative control in the form of hand surface bacteria without hand sanitizer (Figure 2-A), and positive control in the form of hand surfaces that use commercial brand hand sanitizer (Figure 2-B). The results of the study obtained hand sanitizer the most effective in killing and inhibiting the growth of bacteria, namely hand sanitizer with an eco-enzyme fermentation time of 3 months in a dilution ratio of 5: 40, which can be seen in Figure 2-C. This is indicated by the number of colonies growing on the surface of the medium only overgrown with fewer colonies compared to other hand sanitizer samples. In addition, hand sanitizers with a 3-month time variation and a dilution ratio of 5:40 (Figure 2-C) can be compared to hand sanitizers branded in Figure 2-B, where the growth in the number of colonies after inclusion for 48 hours is very small. This proves that the more concentrated the ecoenzyme is used, the more effective hand sanitizer kills or inhibits bacterial growth. 


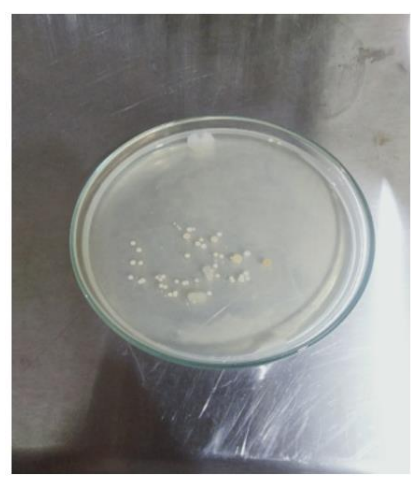

A- Without Hand Sanitizer

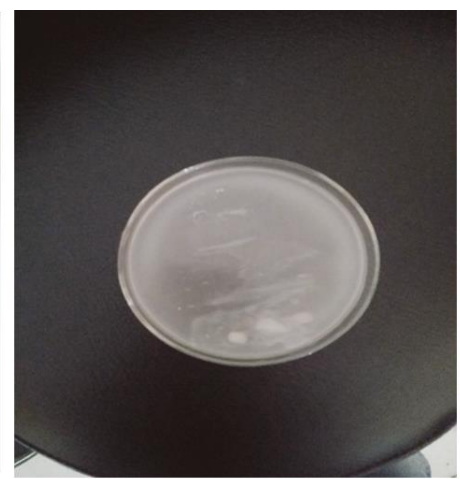

B- Commercial Hand Sanitizer

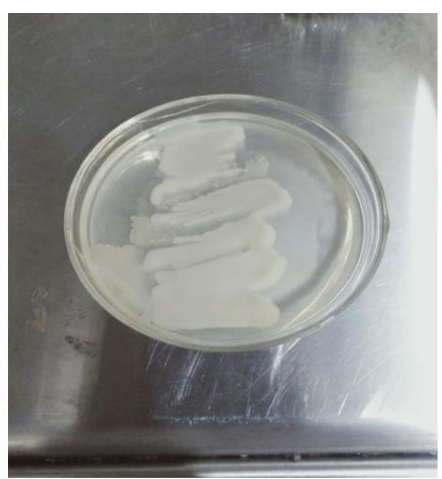

C- Hand Sanitizer 5:40

Eco-enzyme 3 months

Figure 2. Visual performance of bacterial testing by swab method on the palm the hand

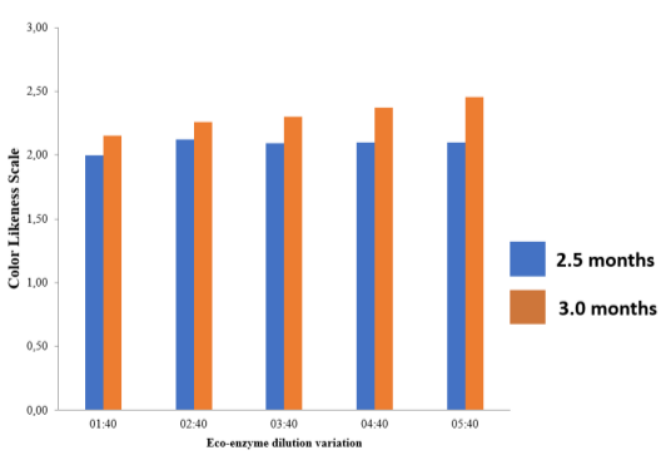

Figure 3. Level of Respondent Preference to the Color of EcoEnzyme Based Hand Sanitizer

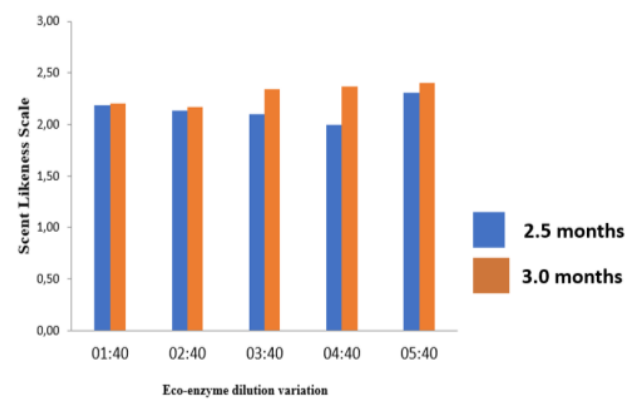

Figure 4. Level of Respondent Preference to the Aroma of EcoEnzyme Based Hand Sanitizer

From Figures 3 and 4, it can be seen that the most accepted hand sanitizer sprays are hand sanitizer sprays made from eco-enzymes fermented for 3 months with a dilution ratio of 5:40.

\section{CONCLUSION}

Based on the results of research, it can be concluded that ecoenzymes that can be used as hand sanitizer sprays are found in the 5:40 dilution sample with 3 months of eco-enzyme fermentation. The liquid emulsion in this hand sanitizer is stable and the $\mathrm{pH}$ value obtained in hand sanitizer spray with a dilution ratio of 5: 40 is 4.5 , where the value meets the quality standard following SNI 06-2588-1992. In addition, a hand sanitizer with a dilution ratio of 5:40 is overgrown with a slight colony, the same as the comparison with the positive control (commercial brand hand sanitizer). The eco-enzyme liquid is brown with the distinctive sour aroma of citrus fruits. The color and aroma are influenced by the raw materials used as well as the length of fermentation. Eco- enzymes with a fermentation time of 2.5 months get a $\mathrm{pH}$ value of 3 , while eco-enzymes with a fermentation time of 3 months get a $\mathrm{pH}$ value of 1.5 .

\section{REFERENCE}

[1] Hasibuan., 2016. Analisis Dampak Limbah/Sampah Rumah Tangga Terhadap Pencemaran Lingkungan Hidup,. Jurnal Ilmiah “Advokasi” Vol. 04. No.1. Hal. 44. Rusdianasari, Jaksen, A Taqwa, Y Wijarnako. 2019. Smart Sensor for Monitoring Integrated wastewater, IOP Conf. Series: Earth and Environmental Science 347, 012061.

[3] Y Bow, A Syakdani, M Taufik, Rusdianasari. 2020. Effect of Drying Airflow Rate on H2O Mass Evaporated on Banana Chips Drying using Photovoltaic Solar Panel, Journal of Physics: Conference Series 1500 (012015).

[4] Istianto, M. dan Muryati., 2014. Manfaat dan Potensi Peningkatan Nilai Ekonomi Limbah Kulit Jeruk, Badan Litbang Pertanian Kementerian Pertanian Republik Indonesia.

[5] Hapsari, D. N. 2015. Pemanfaatan Ekstrak Daun Sirih (Piper Betle Linn) Sebagai Hand Sanitizer. Skripsi. Poltekkes Kemenkes Yogyakarta.

[6] Angraeni, P.D. \& Rahmawati, D.A (2014). Efektivitas Daya Atibakteri Ekstrak Kulit nanas (Ananas comosus) terhadap Pertumbuhan Streptococcus Mutans. Universitas Muhamadiyah Yogyakarta.

[7] Yeragamreddy, P.R., 2013. In Vitro Antitubercular and Antibacterial Activities of Isolated Constituents and Column Fractions from Leaves of Cassia occidentalis, Camellia sinensis, and Ananas comosus. African Journal of Pharmacology and Therapeutics, Vol. 2, No. 4, Pages: 116-123. India.

[8] Mardalena, Warli L., 2011. Milk Quality of Dairy Goat By Giving Feed Supplement as Antioxidant Source. Faculty of Animal Husbandry. Andalas University. Padang.

[9] Santoso H., Soekarto ST., Hermanianto J., 1988. Mempelajari sifat keempukan gula merah. Prosiding. Seminar Penelitian Pasca Panen ; (I), 1-2 Januari 1988. Balai Penelitian dan Pengembangan Pertanian Bogor. Bogor.

[10] Phaichamnan M. Posri W, Meenune M., 2010. Quality Profile Of Palm Sugar Concentrate Produced In Songkhla Province, Thailand. International Food Research Journal. Pages: 425-432

[11] Suheri E. 2016. Gula Aren Atau Gula Merah Sangat Manjur Untuk Mengobati Beragam Penyakit Dan Untuk Daya Tahan Tubuh. http://www.erwinsuheri.com/2016/06/gula-aren-atau- 
gula-merah-sangat

manjur.html.

kesehatan.blogekstra.com/supangkat/khasiat-dan-

manfaatgula-aren.html. Diakses (25 Mei 2021)

[12] Larasati, Destiana., dkk., 2020. Uji Organoleptik Produk

Eco-Enzyme Dari Limbah Kulit Buah (Studi Kasus Di Kota Semarang). FMIPA Unimus.

[13] Nazim, F. \& Meera, V., 2013. Treatment of Synthetic Greywater Using 5\% And 10\% Garbage Enzyme Solution. International Journal of Industrial Engineering and Management Science, Vol. 4, No.3, Pages: 111-117.

[14] Rusdianasari, A Taqwa, Jaksen, Y Wijarnako. 2019. Effectiveness of Electrocoagulation Method in Processing Integrated Wastewater using Aluminium and stainless Steel Electrodes, Journal of Physics: Conference Series 1167 (012040).

[15] Rusdianasari, Y Bow, T Dewi. 2019. Peat Water Treatment by Electrocoagulation using Aluminum Electrodes, IOP Conf. Series: Earth and Environmental Science 258, 012013. 